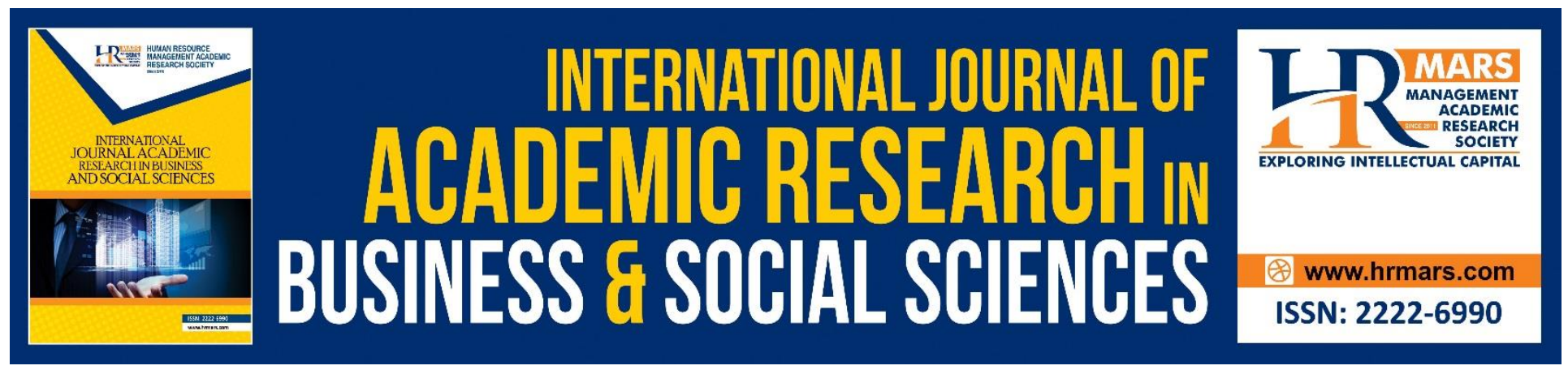

\title{
Prospect of a Flood Micro-Insurance in Malaysia: A Survey of Literatures
}

Fauzilah Salleh, Muhammad Shahrul Adha Salahuddin, Nurul Aswani Jumali, Nur Azla Aziera A'ala, Md. Faruk Abdullah

To Link this Article: http://dx.doi.org/10.6007/IJARBSS/v8-i12/5051

DOI: $10.6007 /$ IJARBSS/v8-i12/5051

Received: 03 Oct 2018, Revised: 13 Nov 2018, Accepted: 17 Dec 2018

Published Online: 28 Dec 2018

In-Text Citation: (Salleh, Salahuddin, Jumali, A'ala, \& Abdullah, 2018)

To Cite this Article: Salleh, F., Salahuddin, M. S. A., Jumali, N. A., A'ala, N. A. A., \& Abdullah, M. F. (2018). Prospect of a Flood Micro-Insurance in Malaysia: A Survey of Literatures. International Journal of Academic Research in Business and Social Sciences, 8(12), 517-527.

Copyright: (c) 2018 The Author(s)

Published by Human Resource Management Academic Research Society (www.hrmars.com)

This article is published under the Creative Commons Attribution (CC BY 4.0) license. Anyone may reproduce, distribute, translate and create derivative works of this article (for both commercial and non-commercial purposes), subject to full attribution to the original publication and authors. The full terms of this license may be seen

at: http://creativecommons.org/licences/by/4.0/legalcode

Vol. 8, No. 12, 2018, Pg. 517 - 527

Full Terms \& Conditions of access and use can be found at http://hrmars.com/index.php/pages/detail/publication-ethics 


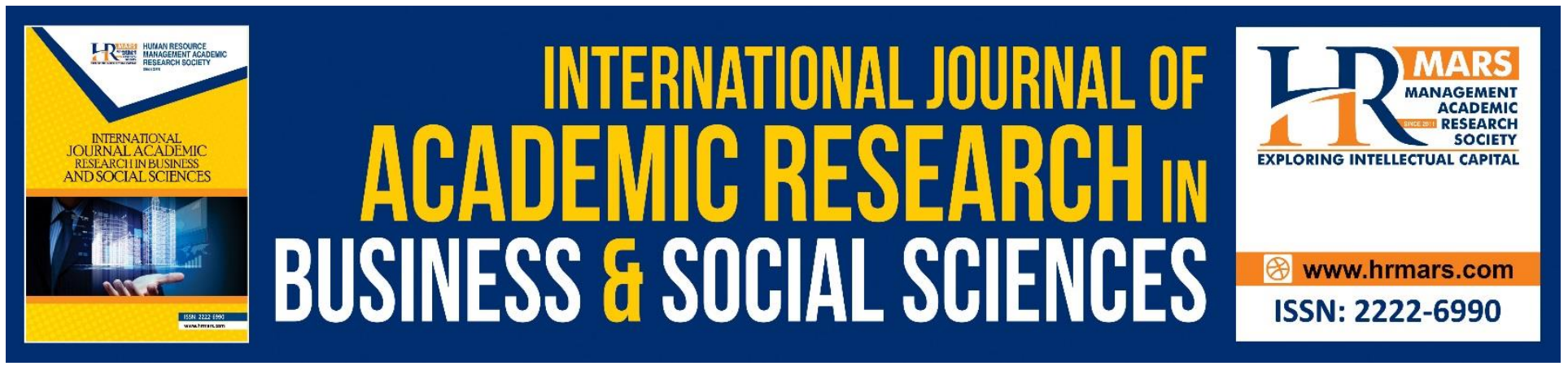

\title{
Prospect of a Flood Micro-Insurance in Malaysia: a Survey of Literatures
}

\author{
Fauzilah Salleh \\ Faculty of Economics and Management Sciences, Universiti Sultan Zainal Abidin, 21300 Kuala \\ Nerus, Terengganu, Malaysia \\ Email: fauzilah@unisza.edu.my
}

\section{Muhammad Shahrul Adha Salahuddin}

Faculty of Economics and Management Sciences, Universiti Sultan Zainal Abidin, 21300 Kuala

Nerus, Terengganu, Malaysia

Email: Shahrul.salahuddin93@gmail.com

Nurul Aswani Jumali

STS 30 (Sinergi DInemik, Suite 6.01, Level 6, Menara AIA, No 68, Jalan Batai Laut 4, Taman Intan, 41300 Klang, Selanor

Email: Nurul.aswanie@gmail.com

\section{Nur Azla Aziera A'ala}

Kenanga Investment Bank Berhad, Level 17, Kenanga Tower, 237, Jalan Tun Razak, 50400 Kuala Lumpur

Email: azlaazieraaala@gmail.com

\section{Md. Faruk Abdullah}

(Corresponding Author)

Faculty of Economics and Management Sciences, Universiti Sultan Zainal Abidin, 21300 Kuala

Nerus, Terengganu, Malaysia

Email: farukabdullah@unisza.edu.my

Abstract: There is no insurance policy in Malaysia which exclusively covers flood as a particular product. The reality of flood coverage in insurance is either it comes as a rider in fire insurance policy or as primary coverage in household/homeowner insurance policy. Perhaps it is due to the reason that flood insurance would require monthly high premium. Moreover, a report from 'Persatuan 
INTERNATIONAL JOURNAL OF ACADEMIC RESEARCH IN BUSINESS AND SOCIAL SCIENCES Vol. 8, No. 12, Dec, 2018, E-ISSN: 2222-6990 @ 2018 HRMARS

Insurance Am Malaysia' stated that Malaysians' purchasing power is becoming smaller and cannot afford for insurance protection mechanism. Thus, micro insurance is a solution since the target customer for this product is the lower income earner. The impressive result from the establishment of flood micro-insurance is that it may reduce people's dependency on the government when the disaster occurs. Therefore, it is necessary for the relevant parties to consider introducing a policy that protects flood victims with affordable rates particularly for those with lower income. Finally, considering the fact that conventional insurance policy is against the principles of Islamic law, a flood micro-takaful can be offered as an alternative to fulfill the interest of the Muslim customers.

Keywords: Micro-insurance, Flood, Lower Income Household/Earner, Centre Bank of Malaysia Insurance Company (insurer)

\section{Introduction}

Flood is an overflow of water that submerges land that is usually dry (Emmanuel Mavhura et al.,2017). The European Union Floods Directive defines flood as a land that are covered by water. In Malaysia, flood coverage under general housing insurance is an extended coverage of risks by paying an additional premium. It is essential to develop flood insurance as a single policy targeted to those who are lower income earner. Massive floods commonly happen in monsoon seasons as the rain stretches out and widespread over the region. States like Pahang, Terengganu, Johor, Kelantan, Sabah and Sarawak frequently confront this season. On the other hand, states like Perlis, Kedah, Penang, Perak, Selangor, Negeri Sembilan, Malacca and W.P Kuala Lumpur regularly get the flash flood. Flash flood is a fast ascent in waterway water levels with a short precipitation.

This study aims to create awareness of micro flood insurance plan as an important alternative to alleviate poverty and protecting people from losses due to this natural disaster by referring to a literature survey. Malaysia needs new insurance product which is capable of covering the loss caused by flood especially the lower income earner. One of the countries which has introduced micro flood insurance is Bangladesh. Micro-insurance is often referred as a competent weapon for reducing, sharing or spreading climate-related costs and risks (Bouwer and Vellinga 2002, Hoff et al. 2003 Mills 2004).

The motivation for having micro-flood insurance comes from the pursuit of finding an efficient way of compensating those lower-income people who suffer losses in rural and urban areas, and to manage their financial risk of uncertain losses. Floods give impact on both individuals and communities and have the social, economic, and environmental outcome. The consequences of floods, both negative and positive are different depending on the location and the extent of flooding, and the vulnerability and value of the natural and constructed environments they affect.

In the UK, the Government and private sector insurers came to have an unwritten Gentlemen's Agreement that led the private sector flood insurance operating in the UK since the early 1960s. It is mandatory for every house owner to subscribe to this insurance policy except in the place where flood rarely happen. The government would still be aware of the risk, and some rewards could even be given for introducing risk-mitigating measures. Although it is not always subsidized, it is a technique to provide potential victims in with some form of coverage after the flood. Based on the above mechanism, both government and insurers need to work closely to overcome this problem. 
INTERNATIONAL JOURNAL OF ACADEMIC RESEARCH IN BUSINESS AND SOCIAL SCIENCES

Vol. 8, No. 12, Dec, 2018, E-ISSN: 2222-6990 @ 2018 HRMARS

There are three approaches for the Malaysian government to overcome flood disaster aftermath:

1. Partially subsidized the contribution;

2. Fully subsidized the contribution;

3. Participation by self-contribution.

The insurance company should collect the premiums and process the claims while the government retains responsibilities for underwritten losses.

There is one objective that this research highlights which is to bring mutual understanding on the overarching of the importance of a micro flood insurance development plan. Nowadays, flood occurs regardless of time and places due to the constant rain for a couple of days. The Malaysia community should be prepared to face the floods regardless of the urban or rural area. Our study demonstrates significantly worse impact and slower recovery for rural areas after the flood, including a more significant impact on their income, sanitation, and electricity supply and less economic improvements within six months. More importantly, there is a need to assist efforts towards the rural population. This is a more robust approach and will require more allocation locally and at a national level.

The subsequent section of the article discusses the basic concepts related to the study followed by the research methodology adopted. It then shows the findings of the literature survey and conclusions and recommendations.

\section{Micro Flood Insurance}

Micro flood insurance is a combination of three elements namely micro flood and insurance which is combined in a single policy. The term 'micro' is referring to a 'small unit' which is assigned to the lower income earner while the term of the flood is alluding to a sole cause of loss covered in the policy. Plus, the term of insurance is connected as one mechanism of protection against uncertainty events. The uncertainty event here is flood disaster. The world nowadays sees the protection as necessary by referring to insurance protection. Micro flood insurance is specially designed to meet social responsibility for low-income groups (Emmanuel Mavhura et al., 2017; Nor Ashikin, et al., 2016; Sonia Akter et al., 2009; Ravindra K. Pande, 2010)

\section{The reality of Flood Disaster in Malaysia}

In 2014, the floods catastrophe destroyed eight districts in Kelantan that damaged public assets and infrastructure with a gross loss approximated about RM200 million. Meanwhile, in Penang, business owners are staring at losses up to RM1 million each from their premises being overrun by the flood over the weekend (Malaysia National Security Council, 2014). Floods in developing countries pose a more significant threat to human life, health, and well-being than in developed countries. Research shows that the impact of the flood on housing and households can be extensive. Fast flowing flood water is able to wash away entire slums while the slowly rising water damages buildings. The damages could be either to public buildings such as hospitals, clinics, educational buildings, and significant religious sites such as mosques and temples leading to further impacts. The national council also revealed that thousands of hectares of agrarian land were harmed in the flood (Nor Ashikin et al., 2016). 
The reality of natural disaster protection in Malaysia in general is that it is not being covered as a basic coverage but only as a rider. Rider in insurance is a right of insuring to add some excluded peril in their insurance coverage by paying additional premium. Insured with the coverage of flood only will be received compensation for their loss or damage of subject matter under general insurance (The General Insurance Association of Malaysia).

\section{The Acknowledgement of Micro Flood Insurance}

Considering the importance of micro flood insurance, supports from the present academics, insurance companies and government are required to implement micro flood insurance plan (Amos Gitau Njuguna \& Abigael Arunga, 2016; Zaiton Hamin et al., 2013; Nor Ashikin et al., 2016).

\section{Academician:}

The academicians bear the responsibilities to carry out continuous studies of micro flood insurance to provide sufficient reference toward government and insurance companies.

\section{Government:}

At the government side (), Bank Negara Malaysia (the Central Bank of Malaysia) plays a vital roles as a regulator through guiding and facilitating insurance companies to offer a product of micro flood insurance (The Discussion Paper on Microinsurance/Microtakaful by BNM 2016; Zaiton Hamin et al., 2013)

\section{Insurance companies:}

The licensed general insurance companies are responsible to develop micro flood insurance plan as well as to promote insurance protection among lower income earner. The collaboration between government and insurance companies is required for enhancing the product that has been suggested (Nor Ashkin et al., 2016; Amos Gitau Njuguna \& Abigael Arunga, 2016).

\section{Research Methodology Content Analysis}

This study provides a content analysis of research articles which presents the development of micro flood insurance. The definition of content analysis is "any technique for making inferences by objectively and systematically identifying specified characteristic of messages" (Holsti, 1969). The objective of this study is to identify the importance of micro flood insurance plan and the loss or damage suffered by household caused by the flood.

Figure 1 presents the content analysis process. These processes start with the sample selection where the article is selected. The second stage is specifying the unit of analysis and then followed by the third stage which is determining the category scheme. In the fourth stage is the selection for the final categories and reliability analysis to identify the level of agreement between the judges. The last stage analyzes and interprets the data. 
INTERNATIONAL JOURNAL OF ACADEMIC RESEARCH IN BUSINESS AND SOCIAL SCIENCES Vol. 8, No. 12, Dec, 2018, E-ISSN: 2222-6990 C 2018 HRMARS

Selecting Sample: Identifying the Text to be examined

Specifying the Unit of Analysis: Specifying the Themes of 50 Articles.

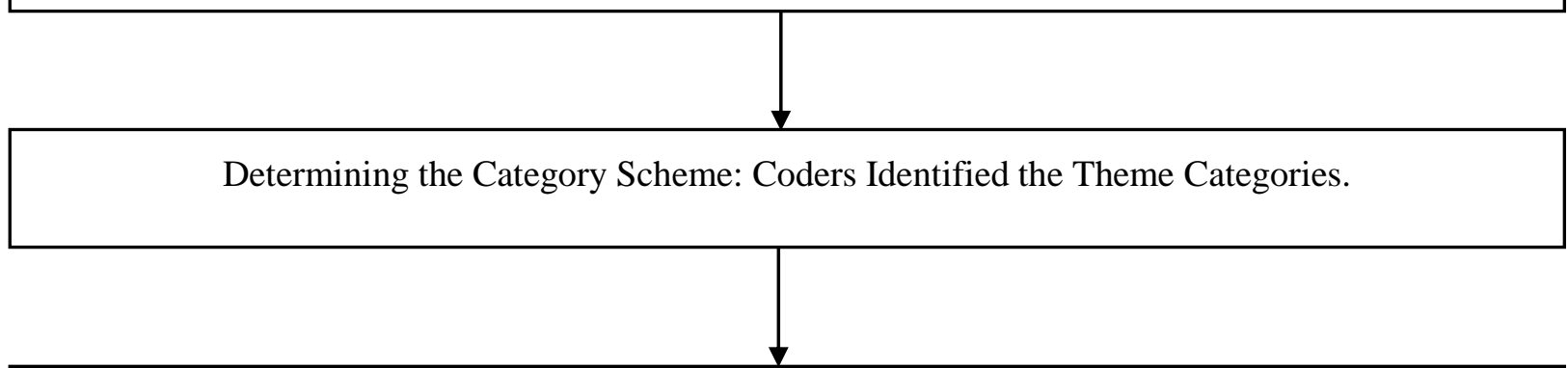

Selection of Final Categories: Judges Coded the Theme of Each Article Using the Category Scheme

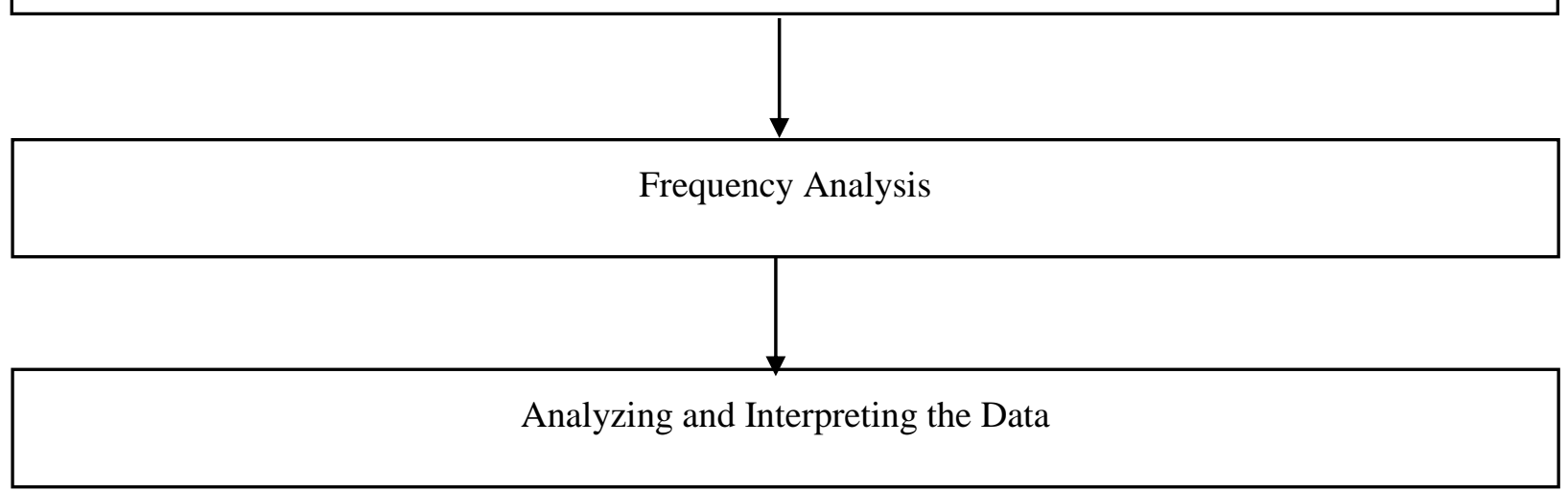

\section{Selecting Sample}

The selected sample of this study are 50 research articles that have been chosen at the beginning of the study. These articles research over the past ten years between 2004 and 2017. The samples obtained from search database (using the library facilities) like Science Direct, Emerald and ProQuest which include the journal with different disciplines. The study sample is also consisting of the articles from the Google Scholar by using the keyword of micro insurance, micro flood insurance, lower income, rural area, and urban area as well as phrases that included in the articles.

\section{Specifying the Unit of Analysis}

The selected samples of the article were combined in one table based on year, title, author and abstract. The researcher needs to determine the main research topic according to the 50 articles by classifying the research articles into the title and abstract as the unit of analysis in order to create the theme of the articles. 


\section{Determining the Category Scheme}

Sonia Akter et al. (2009)'s study on introducing a micro-flood insurance market in Bangladesh: Institutional Design and Commercial Viability was selected as a coder to analyze the list of themes and come up with categories. For the start, 18 themes are randomly selected from the 50 theme to generate coders. The purpose of selection of this article is because of both coder items have been found in the article. Coder 1 is to provide mutual understanding on important of micro flood insurance.

Table 1: Generated categories by coder

\begin{tabular}{|ll|}
\hline \multicolumn{1}{|c|}{ Coder 1} \\
\hline - & $\begin{array}{l}\text { Better preparation for natural disaster to } \\
\text { the poor population. }\end{array}$ \\
\hline - & $\begin{array}{l}\text { Important tool for reducing, sharing or } \\
\text { spreading climate-related costs and risk. }\end{array}$ \\
\hline - & $\begin{array}{l}\text { To ensure that poor people are covered } \\
\text { and the contribution is paid on time. }\end{array}$ \\
\hline - & $\begin{array}{l}\text { As an alternative for poverty alleviation } \\
\text { and strategy for natural disaster risk } \\
\text { coping. }\end{array}$ \\
\hline - & $\begin{array}{l}\text { Influencing factors in the development } \\
\text { micro flood insurance. }\end{array}$ \\
\hline
\end{tabular}

Table 1: Coder 1

\section{Selecting the Final Categories}

1. "Demographic" category: Identify on (i) the total population affected during the flood occurrence and (ii) the geographical areas which affected by flood.

2. "Government responsibility" category: Provide financial aid support to the victims especially for lower income group post flood disaster.

3. "Important of risk mitigation" category: As the preparation and tools to reduce sharing or spreading climate-related cost and risk.

4. "Development of micro flood insurance" category: Factors that influence the development of micro flood insurance, alternative for poverty alleviation and strategy for natural risk reduction on loss of property.

\section{Frequency Analysis}

Frequency analysis is a descriptive statistical method that shows the number of occurrences of each response chosen by the respondents. Based on the articles that we choose, we decided to focus on the frequency of important of micro flood insurance. 
INTERNATIONAL JOURNAL OF ACADEMIC RESEARCH IN BUSINESS AND SOCIAL SCIENCES Vol. 8, No. 12, Dec, 2018, E-ISSN: 2222-6990 @ 2018 HRMARS

Table 2: The percentage of classification of the articles

\begin{tabular}{|l|c|c|}
\hline Item & Frequency & Percentage \\
\hline Importance of micro flood insurance & $13 / 50$ & $26 \%$ \\
\hline Reducing the number of poverty & $3 / 13$ & $23 \%$ \\
\hline As a financial aid & $7 / 13$ & $54 \%$ \\
\hline Protect lower income earner & $6 / 13$ & $46 \%$ \\
\hline To show the government's concern and role & $5 / 13$ & $38 \%$ \\
\hline As a risk mitigation (tools) & $7 / 13$ & $54 \%$ \\
\hline
\end{tabular}

Among the 50 articles, only 13 articles which are $26 \%$ are related to our research objective. From 13 articles, three articles are focusing on reducing poverty. The most important which is micro flood insurance is $54 \%$, which is equivalent to seven articles. Seven out of 13 articles were focusing on the most influencing factor on the importance of the development of micro flood insurance which it mitigate risk and financial and support for lower income group. Each contributes a 54\%. Six articles were related to the second important element of developing micro flood insurance is protecting lower income group. This point contributes $46 \%$. Five articles were related to the third importance of developing micro flood insurance is showing the government's concern \& role towards income group. This point contributes $38 \%$. Three articles were related to the fourth importance that developing micro flood insurance is to reduce poverty among lower income group. This point contributes $23 \%$.

\section{Research Findings}

Based on figure 2, it clearly illustrated the number of articles used which published between the year 2000 and 2017 was total 13. Unfortunately, in 2006 to 2008 no article was released on related issues. Between the year 2000 and 2002, only one article were published while there are two articles were published in years of 2003 to 2005 and 2009 to 2011. However, it seems that academician have shown interest in the study when the number of articulations produced has been increase by three in 2012 and 2014 and an increase to four articles in 2005 to 2017. 


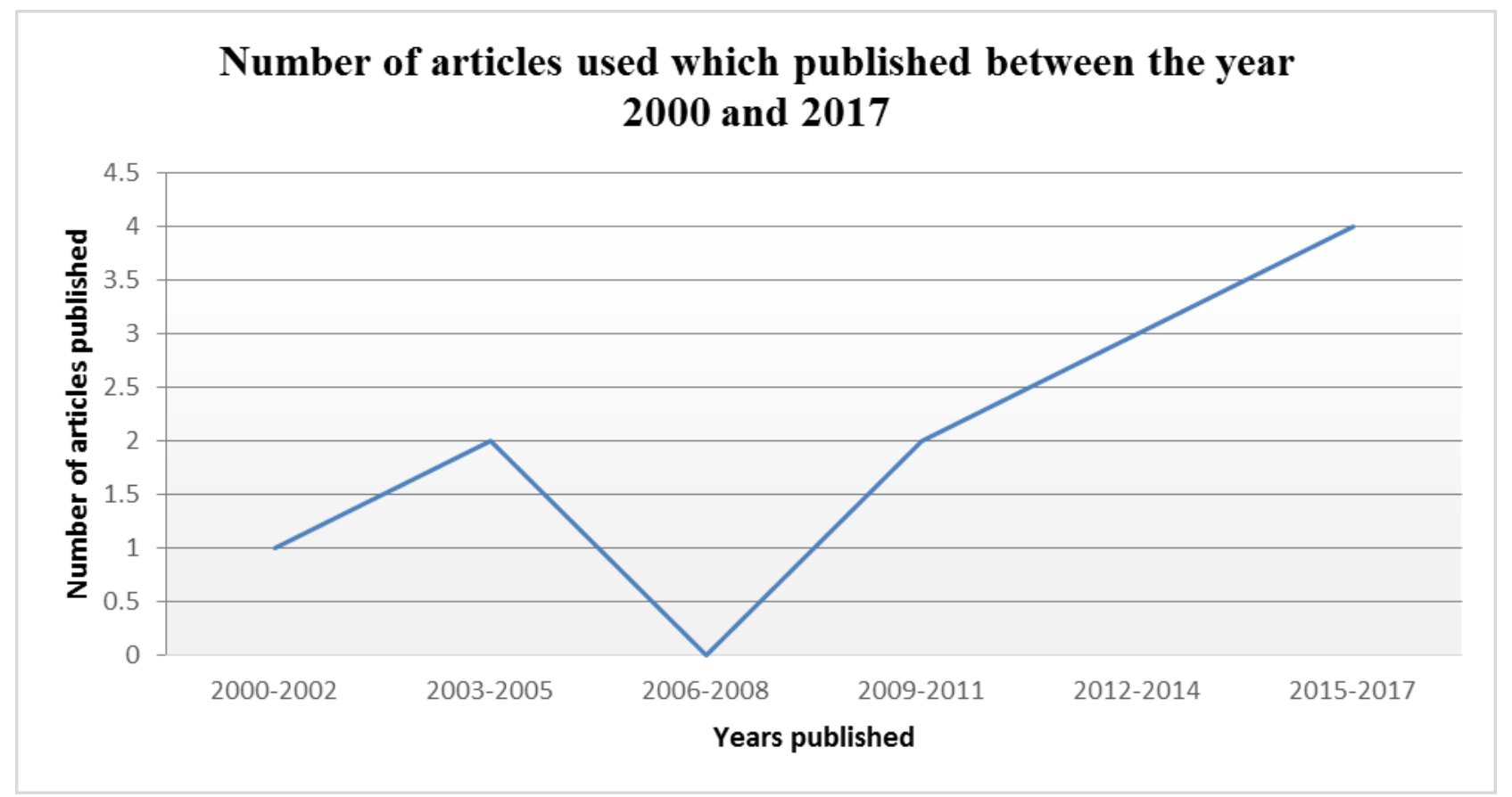

Figure 2: The Number of The Articles Used.

\section{Result of Theme Analysis}

The result of theme analysis is shown in figure 3 . The bar chart displays the number of distribution of 13 articles used in study by themes. It was recognize that the micro flood insurance as a financial aid and risk mitigation has been dominated when the frequency theme being mentioned in 13 articles from years 2000 to 2017 is seven times (54\%). Second, the most studied theme is micro flood insurance as a tool to protect lower income earner when it being quoted six times over the 13 articles $(46 \%)$ and finally 'reduce poverty' with the frequency three times (23\%) much as declared. 


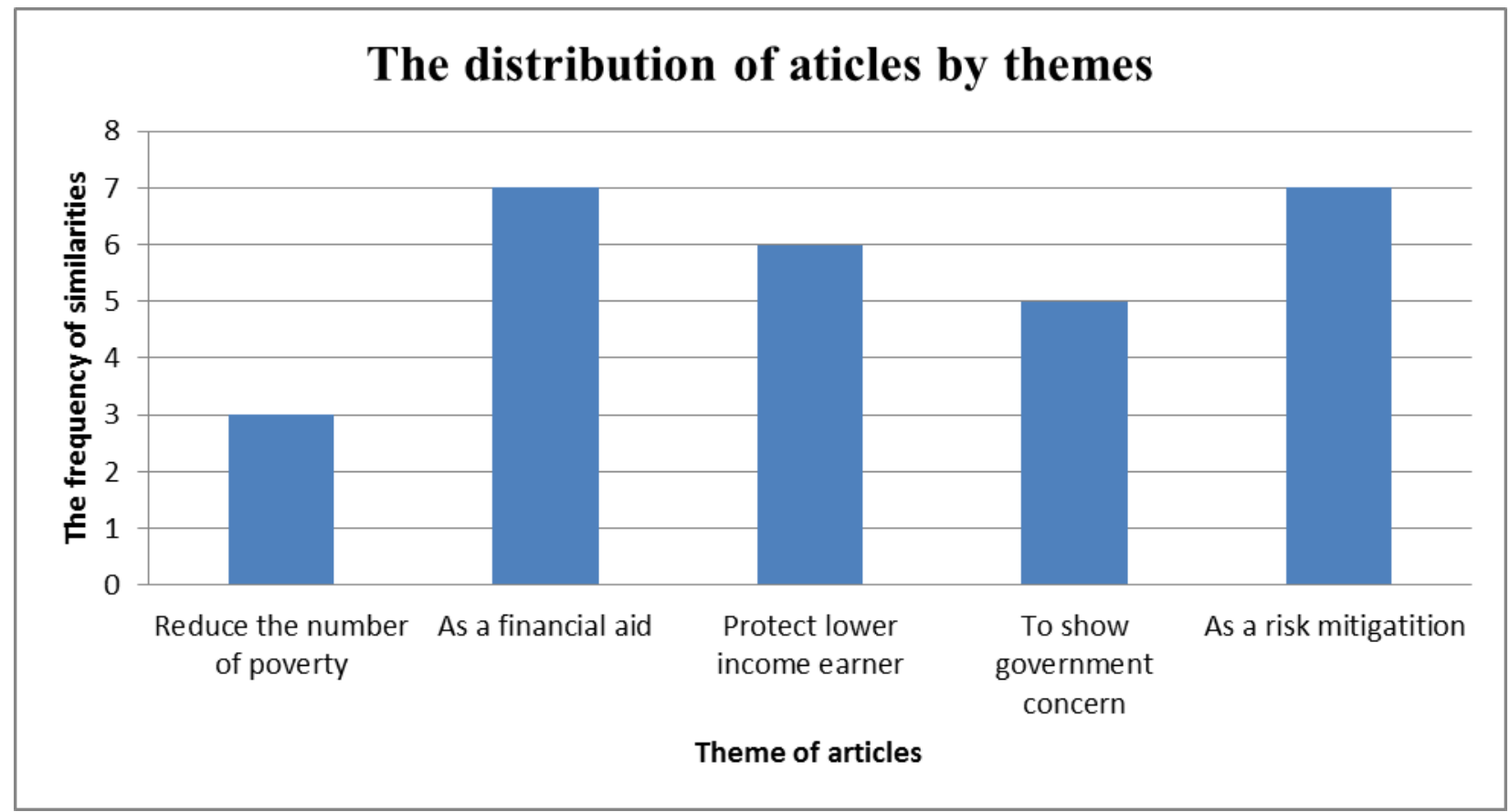

Figure 3: The Distribution of Articles by Themes.

\section{Conclusion and Recommendations}

Micro flood insurance is a combination of three elements namely micro, flood and insurance which combined to become a single policy. The term 'micro' is referring to a 'small unit' which is assigned to the lower income earner while the term 'flood' is alluding to a sole cause of loss covered in the policy. The reality of flood coverage in insurance is it either comes as a rider in fire insurance policy or as primary coverage in household/homeowner insurance policy. About 8,411,581 people (2016) in Malaysia are classified as people with low income. This is a significant amount of people exposed to loss and damage caused by flood. Previous studies have proven that micro flood insurance in Bangladesh (Sonia Akter et al., 2009), United States (David Shively, 2017) and Netherland (Paudel et al., 2014) have positive impact on individuals, communities and the nation itself. In Malaysia, it is essential to develop micro flood insurance as a separate policy for those lower income earners.

To this end, it is noteworthy to mention that conventional insurance is not in line with the interest of the Muslims who hold the majority position in Malaysia. From Islamic perspective, conventional insurance involves uncertainty (gharar), gambling (maysir) and interest (riba). Islamic legal sources prohibit involving in any of these three elements. Therefore, takaful has been introduced as an alternative for insurance. Since the inception of takaful in Malaysia, it has been proven a viable alternative to insurance. This is because takaful is able to offer the similar types of products as offered by the conventional insurance and at the same time follows the principles of Islamic law. However, takaful's products are not confined to the Muslims rather it can be offered to any person regardless of his/her religious background. Therefore, this study recommends that flood micro-takaful should be offered too as an alternative choice to conventional micro-insurance. 
INTERNATIONAL JOURNAL OF ACADEMIC RESEARCH IN BUSINESS AND SOCIAL SCIENCES

Vol. 8, No. 12, Dec, 2018, E-ISSN: 2222-6990 C 2018 HRMARS

\section{References}

Biener, C., \& Eling, M. (2009). The Performance of Microinsurance Programs:.

W. Njeru, D., \& Waiganio, D. (2017). Factors Influencing Demand for Micro insurance Services in the Insurance Industry in Kenya.

Abbas, A., Babu, S., Ka chele, H., \& Muller, K. (2014). Non-structural flood risk mitigation under developing country conditions : an analysis on the determinants of willingness to pay for flood insurance in rural pakistan.

Akotey, O. J., A.Osei, K., \& Gemegah, A. (2011). The Demand for Micro Insurance in Ghana.

Bakhtiari, S. (2013). Microinsurance and Microtakaful : Strategies for poverty reduction towards sustainable development.

C. Penning- Rowsell , E., \& J.priest, s. (2015). Sharing the burden of increasing flood risk : who pays for flood insurance and flood risk management in the United Kingdom.

Green, C., \& Penning-Rowsell, E. (2004). Flood Insurance and Government : " Parasitic " and " Symbiotic" Relations.

Hamina, Z. , Othman, M., \& Elias, Z. (2013). Floating on a Legislative Framework in Flood Management in Malaysia : Lessons from the United Kingdom.

Ime, F. B., \& Ikechukwu, A. (2017). Microinsurance and Its Untapped Economic Development Potential in Nigeria.

J.Browne, M. (2000). The demand for flood insurance : Empirical Evidence.

Mohd Rom, N., Md Hassan, N., \& Ab Rahman , Z. (2016). National Flood Insurance : Funding Model for Citizens at lower Strata of Economic.

Njuguna, A. G., \& Abigael, A. (2012). Risk Management Practices : A survey of Micro -Insurance Service Providers in Kenya.

Zou, H. (2003). Corporate insurance market in the people's republic of china : some macro and micro perspectives. 